\title{
Integration of High Temperature Gas Reactors With In Situ Oil Shale Retorting
}

\section{ICENES}

Eric P. Robertson

Michael G. McKellar

Lee O. Nelson

The INL is a

U.S. Department of Energy

National Laboratory

operated by

Battelle Energy Alliance

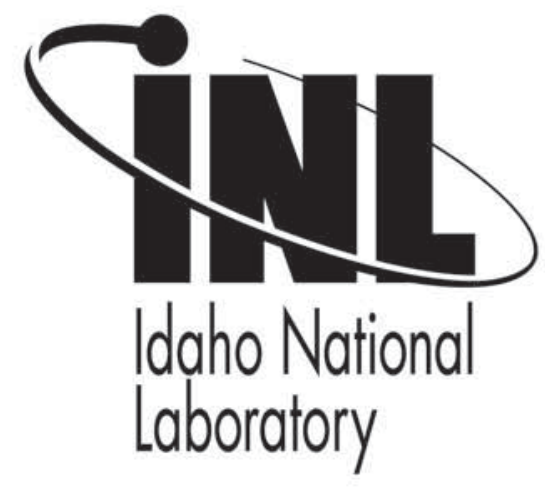

\section{May 2011}

This is a preprint of a paper intended for publication in a journal or proceedings. Since changes may be made before publication, this preprint should not be cited or reproduced without permission of the author. This document was prepared as an account of work sponsored by an agency of the United States Government. Neither the United States Government nor any agency thereof, or any of their employees, makes any warranty, expressed or implied, or assumes any legal liability or responsibility for any third party's use, or the results of such use, of any information, apparatus, product or process disclosed in this report, or represents that its use by such third party would not infringe privately owned rights. The views expressed in this paper are not necessarily those of the United States Government or the sponsoring agency. 


\title{
INTEGRATION OF HIGH TEMPERATURE GAS REACTORS WITH IN SITU OIL SHALE RETORTING
}

Eric P. Robertson, Michael G. McKellar, Lee O. Nelson

\author{
Idaho National Laboratory, \\ PO Box 1625, MS 2107, Idaho Falls, ID, USA \\ eric.robertson@inl.gov,michael.mckellar@inl.gov,lee.nelson@inl.gov
}

This paper evaluates the integration of a hightemperature gas-cooled reactor (HTGR) to an in situ oil shale retort operation producing $7950 \mathrm{~m}^{3} / \mathrm{D}(50,000$ bbl/day). The large amount of heat required to pyrolyze the oil shale and produce oil would typically be provided by combustion of fossil fuels, but can also be delivered by an HTGR. Two cases were considered: a base case which includes no nuclear integration, and an HTGRintegrated case.

The HTGR was assumed to be physically located near the oil shale operation such that heat losses during surface transport of the heating fluid were negligible. Transferring the required retort heat for all three cases to the underground oil shale was modeled by a series of closed-loop pipes. The pipes ran from the surface to the desired subsurface zone where the majority of the heat was transferred to the oil shale; the cooled fluid was then returned to the heat source at the surface for reheating. The heat source was a natural gas fired boiler for the base case and was an HTGR for the HTGR-integrated case. The fluid and heat flows through the circulation systems were modeled using Hyprotech's HYSYS.Plant ${ }^{\mathrm{TM}}$ process modeling software.

A mass and energy balance model was developed to evaluate oil production, gas production and usage, electricity generation and usage, heat requirements, and $\mathrm{CO}_{2}$ emissions for each case. Integrating an HTGR to an in situ oil shale retort operation appeared quite feasible and had some notable advantages over the base case. The $H T G R$-integrated case produced the same amount of refinery-ready oil, four times the amount of gas, $8 \%$ of the amount of $\mathrm{CO}_{2}$, and $70 \%$ of amount of electricity as the base case evaluated with retort heat coming from combustion of fossil fuels.

\section{INTRODUCTION}

This paper addresses potential integration opportunities for single or multiple High Temperature Gas-cooled Reactor (HTGR) modules with production of oil from an in situ oil shale retort process. An HTGR module produces process heat (steam or high-temperature helium), electricity, and/or hydrogen. An HTGR outlet tempera- ture of $750^{\circ} \mathrm{C}$ for the primary fluid loop is assumed for this study, which reflects the initial HTGR design and assumes a conservative outlet temperature; temperatures of $950^{\circ} \mathrm{C}$ are anticipated for advanced HTGR designs.

In conventional chemical processes, process heat, electricity, and hydrogen are generated by the combustion of fossil fuels such as coal and natural gas, resulting in significant emissions of greenhouse gases such as carbon dioxide. An HTGR could produce and supply these products to conventional chemical processes without generating any greenhouse gases. The use of an HTGR to supply process heat, electricity, or hydrogen to conventional processes is referred to as an HTGR-integrated process.

The oil resource within the Green River Formation oil shale deposits in Colorado, Utah, and Wyoming is over $4.8 \times 10^{11} \mathrm{~m}^{3}$ (3 trillion barrels). ${ }^{1,2,3}$ The total recoverable oil from this resource is estimated to be about $2.2 \times 10^{11} \mathrm{~m}^{3}$ (1.4 trillion barrels), ${ }^{3}$ which is greater than the $1.7 \times 10^{11} \mathrm{~m}^{3}$ (1.1 trillion barrels) of total historical world oil production. ${ }^{4}$ Comparing these historical and potential oil recoveries shows that the oil shale recoverable resource is very, very large and that commercial oil production from oil shale will likely continue for many decades and perhaps centuries due to the huge quantity of the resource.

There are no commercial scale in situ oil shale operations anywhere in the world at this time. However, fieldscale research, development, and demonstration projects are currently operating in western Colorado and eastern Utah. A large-scale, commercial in situ oil shale industry in the U.S. may emerge within the next 10 to 15 years. Even though there are no commercial in situ oil shale operations, numerous reports and analyses have been written and performed from which to draw the parameters necessary to perform an analysis of a hypothetical in situ oil shale production operation and its integration with an HTGR. Development and deployment of a commercial HTGR may also require 10 to 15 years. Thus, this conceptual study of integrating an HTGR with an in situ oil operation is timely.

The process of heating oil shale in an anoxic environment to pyrolyze the kerogen embedded within the oil 
shale and produce oil and gas is commonly called retorting. Kerogen is the organic portion of oil shale and is largely insoluble in organic solvents because of its very large molecular structure. If buried at sufficient depth, time, and concentration, kerogen will release oil and gas; however, kerogen-rich oil shale deposits have not been buried at sufficient depths for oil and gas to form naturally. Retorting the oil shale is a heat-intensive method to convert the kerogen in the oil shale to oil and gas.

A schematic diagram of an in situ oil shale retort operation developed by American Shale Oil LLC is shown in Figure 1. Heat is supplied to the retort zone through a closed-loop piping system. The circulating fluid does not directly contact the oil shale, but transfers its heat by conduction through the pipe wall. Oil and gas are produced through small-diameter vertical production wells.



Figure 1. A schematic diagram of a possible configuration for the production of oil from an in situ oil shale retort operation.

\section{MASS BALANCE - PRODUCTION FROM IN SITU RETORT}

Oil is produced from oil shale by pyrolyzing the kerogen at temperatures above $370^{\circ} \mathrm{C}$ to generate oil, gas, and char. Product generation was calculated by balancing the carbon and hydrogen atoms in the kerogen with the carbon and hydrogen atoms in the product molecules (char, oil, and gas). ${ }^{5}$ The mass balance of the generated products per mass of kerogen is listed in Table I.
Table I. Kerogen pyrolysis mass balance for in situ retort. Units are mass of product per mass of kerogen.

\begin{tabular}{lc}
\hline Product & Calculated Value \\
\hline Char & 0.286 \\
Gas & 0.196 \\
Shale oil & 0.518 \\
Total of products & 1.000 \\
\hline
\end{tabular}

The produced char is a solid that is left in place within the oil shale retort zone, while the oil and gas are mobile and able to flow through the subsurface to production wells. The shale oil is high quality oil with a specific gravity of $0.82 \mathrm{~g} / \mathrm{mL}\left(40^{\circ} \mathrm{API}\right)$. The produced gas has a high heat content of about $65.9 \mathrm{MJ} / \mathrm{m}^{3}(1770 \mathrm{Btu} / \mathrm{scf})$ compared to common natural gas, which has a heat content of about $37.2 \mathrm{MJ} / \mathrm{m}^{3}(1000 \mathrm{Btu} / \mathrm{scf})$.

Based on the mass balance values shown in Table I, the amounts of the pyrolysis products were calculated per tonne of in-place, raw oil shale ore. Table II shows the pyrolysis products in various units per tonne of oil shale.

Table II. Amounts of each in situ pyrolysis product in various forms per tonne of raw oil shale ore. Amount of Fischer Assay oil is shown for comparison.

\begin{tabular}{|c|c|c|c|c|}
\hline \multirow{2}{*}{\multicolumn{2}{|c|}{ Pyrolysis product }} & \multicolumn{3}{|c|}{ Generated product per tonne } \\
\hline & & $\mathbf{m}^{3}$ & MJ & kg \\
\hline In situ & Oil & 0.0835 & 3110 & 69.0 \\
\hline pyrolysis & Gas & 59.8 & 1340 & 26.0 \\
\hline products & Char & - & 1120 & 38.0 \\
\hline \multicolumn{2}{|c|}{ Fischer Assay oil } & 0.105 & 4280 & 98.5 \\
\hline
\end{tabular}

\section{MODELING THE INTEGRATION OF HTGR HEAT TO IN SITU OIL SHALE PRODUCTION}

Two oil shale production cases were identified for modeling:

1. A base case concept of in situ oil shale retort in which a subsurface retort interval is heated by circulating steam through a closed-loop piping system drilled horizontally through the retort interval. The high-pressure steam is heated in a gas-fired burner.

2. An HTGR-integrated case, which is the same as the base case except the gas-fired burner is replaced by a heat exchanger taking heat from an HTGR.

A schematic block flow diagram of the base case concept of an in situ oil shale retort is shown in Figure 2. Products include light oil, similar in gravity to a highquality conventional crude oil; a high heat content gas; electricity, and carbon dioxide. A portion of the produced gas is burned to provide heat to the heating fluid loop and the rest is sold. A power cycle is added to the heating fluid loop between the in situ retort and the combustor in order to reduce the temperature of the returning heat transfer fluid to the maximum pumping temperature. 


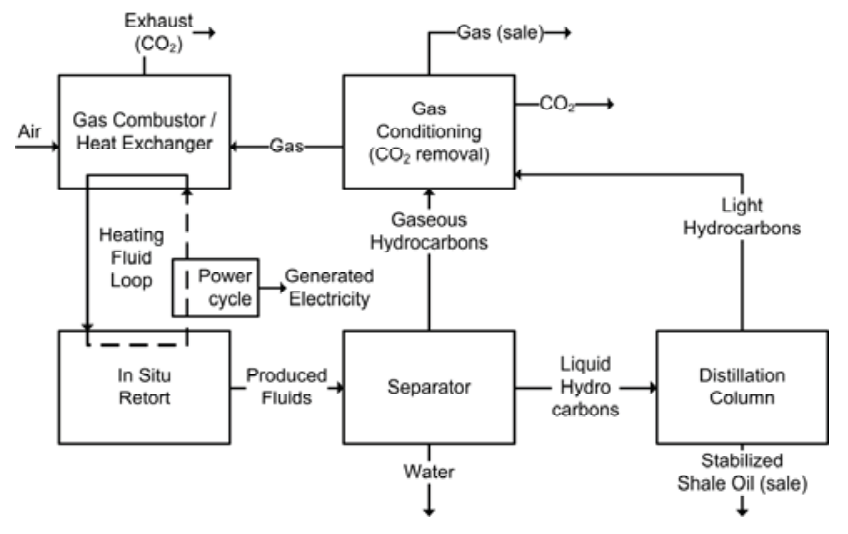

Figure 2. Simplified block flow diagram for the base case concept of an in situ oil shale retort operation.

The simplified block flow diagram for the HTGRintegrated case is shown in Figure 3. The natural gas combustor used in the base case is replaced by an HTGR/heat-exchanger located nearby that supplies heat to the oil shale operation. In the HTGR-integrated case, the entire high-Btu gas stream is sold instead of burning a portion of it to heat the steam; thus, $\mathrm{CO}_{2}$ emissions from flue gas are eliminated in this case.

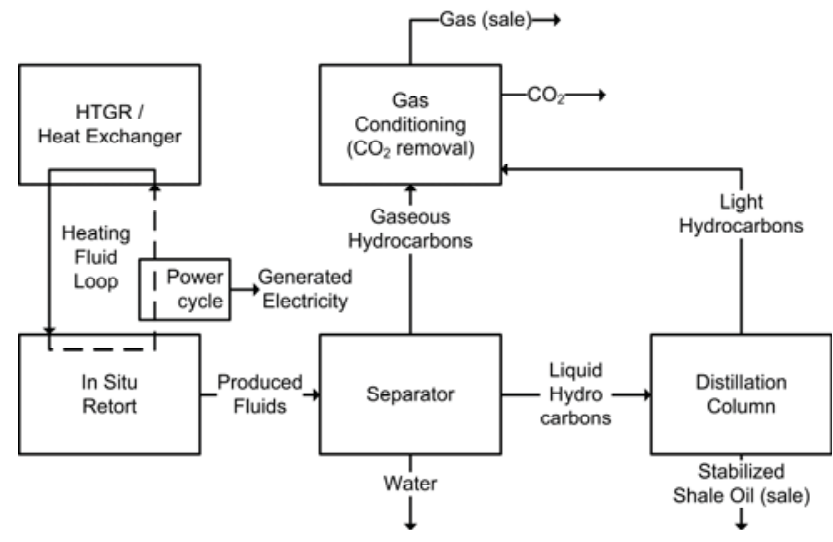

Figure 3. Simplified block flow diagram for an HTGRintegrated in situ oil shale retort operation.

Heat and fluid movement through the heat transfer loops for both cases were modeled using Hyprotech's HYSYS.Plant ${ }^{\mathrm{TM}}$ process modeling software. A single, closed heat transfer loop was modeled and then scaled up to match the required heat transfer rate to produce 7950 $\mathrm{m}^{3} / \mathrm{D}(50,000 \mathrm{bbl} /$ day $)$ of shale oil.

Figure 4 is a simplified schematic drawing of the steam-filled heat transfer loop delivering heat to the subsurface retort zone. The fluid, circulated through the loop by a pump, is heated by transferring heat from hot fluids either from combustion gases (base case) or from hot helium (HTGR-integrated case).

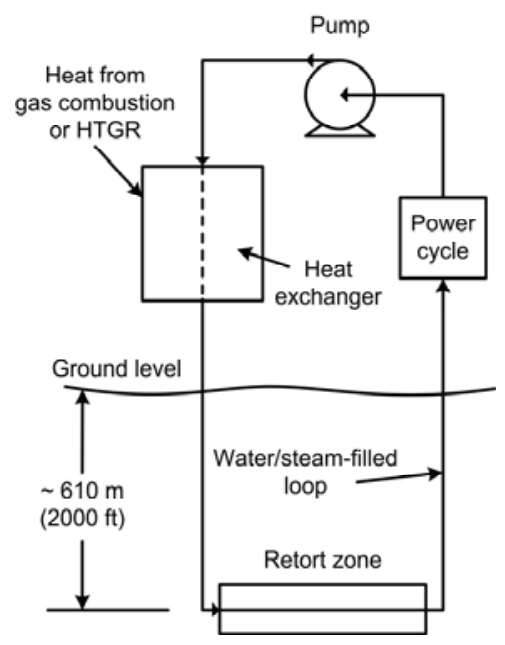

Figure 4. Simplified schematic drawing of steam-filled heat transfer loop delivering heat to subsurface retort zone.

The system was modeled assuming that all the flow lines were $20.3-\mathrm{cm}\left(8\right.$-inch) diameter pipes, ${ }^{6}$ the surface pipes were covered with $10.1 \mathrm{~cm}$ (4 inches) of insulation, the vertical subsurface sections used vacuum-insulated tubing, and the horizontal section running through the retort zone was uninsulated pipe to achieve the greatest heat conduction rate to the oil shale formation.

The power cycle placed downstream of the retort zone and upstream of the circulation pump reducd the temperature of the fluid to the maximum allowable temperature of the pump. By implementing a power cycle, some of the heat could be converted into usable energy.

For the HTGR-integrated case, the energy content of the fluid exiting the HTGR was calculated to be 1007 MW. For the base case, the heat content of the combustions gas was calculated to be $1122 \mathrm{MW}$.

\section{ENERGY BALANCE}

Assumptions, calculations, and details pertaining to the energy balance are located in Appendix A. To produce $7950 \mathrm{~m}^{3} / \mathrm{D}(50,000 \mathrm{bbl} /$ day $)$ of shale oil, the required heat transfer rate to the subsurface retort zone was calculated to be $590 \mathrm{MWth}$. This is the total heat transfer rate that needs to occur through the horizontal heater wells drilled through the retort zone. A number of heater wells must be employed simultaneously to achieve the necessary heat transfer rate to the retort zone.

The energy output from the HTGR or the gas burn$\mathrm{er} / \mathrm{steam}$ boiler is equal to the required energy to retort oil shale and produce $7950 \mathrm{~m}^{3} / \mathrm{D}(50,000 \mathrm{bbl} /$ day $)$ of shale oil plus any other losses or uses.

\section{IV.A Energy Input}

The energy input into each case includes all heat and electricity necessary to operate the systems. For the base 
case, this includes the heat content of the gas being burned in the gas boiler and the electricity necessary to run the circulation pump and surface facilities. The energy input for the base case is $1131 \mathrm{MW}$.

For the HTGR-integrated case, the energy input includes the heat content of the helium exiting the HTGR, the electricity necessary to circulate the helium heat transfer loop, electricity necessary to circulate the steam heat transfer loop, and the electricity necessary to operate the other surface facilities. The energy input for the HTGRintegrated case is $1047 \mathrm{MW}$.

\section{IV.B Energy Output}

Total energy output is the energy content of the produced oil, gas, and electricity. Both cases produce the same amount of oil, gas, and electricity. After converting the heat content flow of these streams to similar units, they sum to $5027 \mathrm{MW}$.

\section{IV.C Energy Balance Summary}

The energy balance for two cases was determined and the energy return on investment (EROI) was calculated. The EROI is the ratio of the total energy outputs to the total energy inputs described in the previous paragraphs. The EROIs for the base case and the HTGRintegrated case are 4.44 and 4.80 respectively. The energy inputs, outputs, and EROIs for each case are summarized in Table III. As a comparison, Lerwick ${ }^{7}$ estimated an EROI of 10.5 for conventional petroleum recovery and 5.0 for steam-assisted gravity drainage recovery of Canadian oil sands.

Table III. Energy input and output values used to calculate the EROI for the base case and the HTGR-integrated case using default valued for the input parameters. ${ }^{a}$

\begin{tabular}{|c|c|c|}
\hline & Base case & HTGR case \\
\hline \multicolumn{3}{|l|}{ Energy Output } \\
\hline Oil total, MW & 3431 & 3431 \\
\hline Gas total, MW & 1482 & 1482 \\
\hline Electricity total, MW & 114 & 114 \\
\hline Total output, MW & 5027 & 5027 \\
\hline \multicolumn{3}{|l|}{ Energy Input } \\
\hline Boiler output, MW & 1122 & - \\
\hline HTGR, MW & — & 1007 \\
\hline Steam pump, MW & 3 & 3 \\
\hline Helium circulator, MW & 一 & 30 \\
\hline Processing facilities, MW & 6 & 6 \\
\hline Total input, MW & 1131 & 1047 \\
\hline EROI, $\mathbf{M W}_{\text {out }} / \mathbf{M W}_{\text {in }}$ & 4.44 & 4.80 \\
\hline
\end{tabular}

\footnotetext{
a The EROI calculations do not include energy used to capture, compress, and sequester any produced carbon dioxide for either case
}

\section{CARBON DIOXIDE EMISSIONS}

$\mathrm{CO}_{2}$ emissions result from decomposition of the oil shale mineral and from combustion of fossil fuels. The total amount of $\mathrm{CO}_{2}$ emitted is the sum of the $\mathrm{CO}_{2}$ emitted in the flue gas stream and the $\mathrm{CO}_{2}$ emitted as a result of the decomposition of kerogen and minerals. Table IV shows the total $\mathrm{CO}_{2}$ emitted for both cases.

Table IV. Total $\mathrm{CO}_{2}$ emitted from a $7950 \mathrm{~m}^{3} / \mathrm{D}(50,000$ bbl/day) in situ oil shale operation.

\begin{tabular}{lcc}
\hline \multirow{2}{*}{ Case } & - Total $\mathbf{C O}_{\mathbf{2}}$ Emitted - \\
& $\mathbf{m}^{\mathbf{3}} / \mathbf{D}$ & tonne/D \\
\hline Base Case & $3,203,000$ & 5,982 \\
HTGR-Integrated Case & 259,000 & 483 \\
\hline
\end{tabular}

\section{HEAT TRANSPORTATION DISTANCE IN SURFACE LINES}

A $7950 \mathrm{~m}^{3} / \mathrm{D}(50,000 \mathrm{bbl} /$ day $)$ in situ oil shale operation can be expected to expand in the subsurface at a rate of $0.278 \mathrm{~km}^{2} / \mathrm{yr}(68.6 \mathrm{ac} / \mathrm{yr})$ based on an oil shale grade of $0.105 \mathrm{~m}^{3} /$ tonne $(25.2 \mathrm{gal} /$ ton $)$, the oil shale retort zone thickness of $71.6 \mathrm{~m}(235 \mathrm{ft})$, and a recovery efficiency of $80 \%$. Assuming an operational life of an HTGR is 30 years, the retorting area would expand to just over $8 \mathrm{~km}^{2}$ $\left(2000 \mathrm{ac}\right.$ or $\left.3.2 \mathrm{mi}^{2}\right)$. If the retort expanded around a centrally located HTGR, the maximum distance the HTGR heat would be transported on the surface would be $1.6 \mathrm{~km}$ (1.0 mi.). If the HTGR operational life were assumed to be 60 years, the maximum surface heat transportation distance would be $2.3 \mathrm{~km}$ (1.4 mi.).

In the Piceance Basin, the total thickness of the oil shale is close to $3048 \mathrm{~m}(1000 \mathrm{ft})$. A thicker retort zone would reduce the expansion rate and the ultimate retort area would be smaller.

\section{SENSITIVITY ANALYSIS}

By applying a distribution to the values of the input parameters, a probabilistic outcome can be obtained, which yields greater information than a single deterministic result. A probabilistic approach also allows one to determine the critical input variables (those that cause the greatest variance in the calculated output when varied within their distributions).

The calculated EROI was selected as the most significant output parameter, and a probability distribution for this parameter was constructed based on 10,000 iterations of the input parameters.

\section{VII.A Base Case}

The base case EROI distribution is shown in Figure 7. The EROI calculated using the most likely input values was 4.44 , the mean value was 4.58 , and the standard deviation of the distribution was 0.57 . 




Figure 5. Probabilistic distribution of the base case EROI. A normal distribution fit to the data is shown.

A sensitivity analysis was done on the Monte Carlo results to determine which input variables caused the most variance in the EORI outcome. The five most critical input parameters for the base case in descending order of importance were:

- the subsurface heat transfer rate

- the fraction of the oil and gas ultimately recovered

- the composition of the kerogen

- the FA oil to kerogen ratio, and

- the richness of the oil shale ore.

The subsurface heat transfer rate will be a minimum if heat moves through the oil shale formation by conduction alone. Burnham et al. ${ }^{6}$ argued that faster heat transfer rates were possible if thermal fragmentation and fluid convection were included in addition to conduction, but showed no physical data to support the claim. More physical data should be generated and collected on heat and fluid movement through oil shale during an in situ retort if this important input variable is to be better understood.

Other critical input variables are site-specific and their estimates can be better refined once a retort site has been established.

\section{VI.D.2 HTGR-Integrated Case}

The probability distribution for the HTGR-integrated case EROI was very similar to the base case. The EROI using the most likely values for the input parameters is 4.80 (slightly higher than the base case), the mean value is 4.97 , and the standard deviation of the distribution is 0.67 .

The most critical input parameters for the HTGRintegrated case identified by the sensitivity analysis were the same and in the same order as the base case.

\section{SUMMARY, CONCLUSIONS, AND RECOMMENDATIONS}

An in situ oil shale retort operation with output of $7950 \mathrm{~m}^{3}$ (50,000 bbl/day) of refinery-ready shale oil was modeled for two different cases. Results for each of the cases using the most likely input parameters are summarized in Figure 6 showing mass and energy inputs and outputs for each case.


Figure 6. Summary results showing the deterministic net mass and energy input and output values using the most likely input values. Note that $1 \mathrm{Btu}=1.055 \times 10^{3} \mathrm{~J}$.

\section{VII.A Conclusions}

High-heat content hydrocarbon gas is produced in each case during the pyrolysis of the kerogen in the oil shale. Over $75 \%$ of the produced gas in the base case is used to generate the heat needed for the retort process; while in the HTGR-integrated case, the full gas stream is available for sale.

$\mathrm{CO}_{2}$ is produced in both cases, but the base case produces more than 12 times more $\mathrm{CO}_{2}$ than the HTGRintegrated cases. This may become an important economic and environmental issue if future $\mathrm{CO}_{2}$ emissions are restricted by governmental controls or penalties.

In both cases, excess electricity is generated and can be sold as revenue. The base case produces $42 \%$ more electricity than the HTGR-integrated case.

The heat put into the system for the HTGR-integrated case $(1007 \mathrm{MW})$ is less than the heat input for the base case (1122 MW).

The EROI for the base case is 4.44, while the EROI for the HTGR-integrated case is 4.80. These EROI values do not include the energy required to capture, compress, and sequester any generated $\mathrm{CO}_{2}$.

High average temperatures of the heater pipe through the retort zone result in excessive energy losses due to temperature and pressure constraints on the pump circulating the steam and water through the retort zone. 
After 60 years (assumed life of nuclear plant) of oil production, the in situ retorted zone would encompass a subsurface area of just over $16 \mathrm{~km}^{2}$ (4000 ac or $6.4 \mathrm{mi}^{2}$ ). If an HTGR were to be located in the center of this area, the distance from the HTGR to the furthest point of the retort zone would be $2.9 \mathrm{~km}$ (1.8 miles). Transporting heat this distance is not expected to be of concern. If the retort zone thickness were greater than the assumed 71.6 $\mathrm{m}(235 \mathrm{ft})$, the area of the retorted zone could potentially be much smaller.

For both cases, the analysis identified the heat transfer ratio as the most critical input parameter for this case, followed by the recoverable fraction of the generated oil and gas, the composition of the kerogen in the oil shale, the mass of FA oil to kerogen ratio, and the FA grade of the oil shale. Refining the estimates and narrowing the potential distribution of these critical variables through further research would reduce the variability and uncertainty associated with the outcome of these cases.

\section{VII.B Future Work and Recommendations}

The following work is recommended to more fully understand the challenges and advantages of integrating an HTGR to a commercial-scale in situ oil shale retort project:

- Incorporate an economic analysis of the cases evaluated in this paper.

- Understand in greater detail the heat transfer rate from a heated pipe to an oil shale retort zone and incorporate findings to reduce the uncertainty of model results.

- Examine the energy requirements for $\mathrm{CO}_{2}$ capture, compression, and storage; and incorporate them in the energy balance to provide a clearer picture of the comparison between the HTGR-integrated oil shale case and the base case that utilizes fossil fuels to generate the required retorting heat.

\section{ACKNOWLEDGMENTS}

The authors would like to thank Rick Wood for his contributions to the content of the paper and management at Idaho National Laboratory (Phil Mills) for permission to publish this work which was supported by the Idaho National Laboratory and by the U.S. Department of Energy, Office of Nuclear Energy, Next Generation Nuclear Plant program.

\section{REFERENCES}

1. Johnson, R.C., T.J. Mercier, M.E. Brownfield, and J.G. Self, "Assessment of in-place oil shale resources in the Eocene Green River Formation, Uinta Basin, Utah and Colorado," U.S. Geological Survey Digital Data Series DDS-69-BB, Chapter 1 (2010.
2. Johnson, R.C., T.J. Mercier, M.E. Brownfield, M.P. Pantea, and J.G. Self, "An Assessment of In-Place Oil Shale Resources in the Green River Formation, Piceance Basin, Colorado," U.S. Geological Survey Digital Data Series DDS-69-Y, Chapter 1 (2010).

3. Bartis, J. T., T. LaTourrette, L. Dixon, D. J. Peterson, and G. Cecchine, "Oil Shale Development in the United States," prepared by Rand Corporation for the National Energy Technology Laboratory of the U.S. Department of Energy (2005).

4. BP company report "Statistical Review of World Energy 2010," published on-line and available at: http://www.bp.com/productlanding.do?categoryId $=6$ $929 \&$ contentId $=7044622$.

5. Robertson, E.P., "Integration of HTGRs to an In Situ Oil Shale Operation," Idaho National Laboratory document ID: TEV-1029 (2011).

6. Burnham, A. K., R. L. Day, and P. H. Wallman, "Overview of American Shale Oil LLC Progress and Plans," 28th Oil Shale Symposium, Golden, Colorado, 13-15 October (2008).

7. Lerwick, P., "The EGL Oil Shale Process," 26th Oil Shale Symposium, Golden, Colorado, 16-18 October (2006). 